\title{
Nigerian Shoppers/Consumers Preferences for Foreign and Domestic Products: Case Study of Clothes and Shoes
}

Scholastica Ebarefimia Udegbe*

Department of Marketing, Lagos State University, Ojo, Lagos, Nigeria

\begin{abstract}
Based on extant literature, studies have shown that consumers adjust their attitudes toward a product according to its country-of-origin. This could be local home country bias or foreign country bias depending on individual orientation. The study compares Nigerian shoppers/consumer preferences for foreign and domestic produced clothes and shoes. The study focus on general product attributes, marketing activities and buying habits as preference indicators. The study also uses survey data of traders and shoppers to explain the issue. The research was conducted in Lagos and the samples selected include 600 respondents of both youth and adult between the ages of 16-60 years. The data were collected based on convenience sample from shoppers and traders in Lagos shopping malls and also Balogun/Tinubu market in Lagos Island-the most popular market for sales of clothes and shoes in Lagos. Collected data for the research was through questionnaire distribution to both youth and adults. Data were analyzed using descriptive statistics, percentages and t-test analysis. The findings indicated that Nigerian shoppers/consumers show more positive preference to foreign made clothes and shoes than to made in Nigeria, and that they are willing to pay higher price for foreign made clothes and shoes because they know that it is of a superior quality than made in Nigeria ones. Results also suggest that country of manufacture and product quality strongly influence consumer decision of purchasing foreign available clothes and shoes. The study provides insights with respect to Nigerian's preference of foreign made clothes and shoes to locally-made ones.
\end{abstract}

Keywords: Consumers; Preferences; Foreign; Products; Nigerian; Clothes; Shoes

\section{Introduction}

Despite the interest to be self-reliance, imports of goods and services have played a major role in the economic development of developing countries, and in most cases the capacity to produce capital and consumer goods is limited, so there is strong dependence on foreign goods from developed countries. For some years now, locally made products have been facing a number of challenges which are alleged to have inhibited growth and development in Nigeria.

Nigeria is a middle income, mixed economy and emerging market, with GDP growth rate of $3.23 \%$ (June/17), unemployment rate $14.2 \%$ (Dec/16), inflation rate 15.98 (Sep/17), interest rate 14\% (Oct/17). Presently, even though the economy is said to have entered a recovery as at Oct/17, with GDP growing for the first time since $3^{\text {rd }}$ quarter of 2015 , the recovery is still very unstable, and not very visible to the consumers. It is under this economic situation that Nigerians have to transact business with other countries. Likewise, with the rapid increase in competition in the market, marketers that strictly adhere to and cater for the needs of the local products are finding themselves at a disadvantage and gradually losing the competitive advantage that they so much strived to achieve. Moreover, for some products and services, the tastes and preferences of consumers are beginning to converge on some global norms. However, from consumer perspective, reactions to the prevalence of foreign products seem to vary among different customers. On the one hand, in most cases in developing countries, consumers seem to value and admire foreign products and regard such products as a status symbol. On the other hand as well, foreign products are often criticized for threatening the local products and imposing the western cultures on our society, leading to a loss of cultural identity $[1,2]$. However, there is limited understanding whether Nigerian shoppers/consumers prefer foreign made clothes and shoes to local ones or vice versa and what accounts for the choice. Thus, the present study empirically determines the Nigerians' shoppers/consumers perceptions of foreign and locally made clothes and shoes.
There are various factors which influence consumer purchase decision. For example: country of origin, price of the brand fashion, family and friends, brand name, availability, advertising campaigns, consumers' ethnocentrism etc. The study is also designed to find out the buying behavior patterns of Nigerian consumers, attitudes towards foreign and locally made clothes and shoes and the reasons behind the preference, based on the above indicators.

This paper uses survey data of traders and shoppers/consumers to explain whether Nigerian consumers prefer foreign made clothes and shoes to local ones or vice versa and what accounts for the choice. The literature on the subject matter is then reviewed in the light of the research issues being investigated. The research methods are structured to test the hypotheses developed for evaluating the consumer preferences for foreign and locally made clothes and shoes. Finally, the findings are discussed and managerial implications suggested for practicing marketing managers and professionals. This study will not only find out the Nigerian shoppers/consumers preferences for foreign and domestic products, with case study of clothes and shoes, but also add to previous literature for marketers and multinational companies who have connections with the Nigerian market. The findings of the research will also assist multinational corporations to structure and develop a sustainable marketing strategy for the Nigerian market.

*Corresponding author: Scholastica Ebarefimia Udegbe, Lecturer, Department of Marketing, Lagos State University, Ojo, Lagos, Nigeria, Tel: +2348171863906 E-mail: scholasticudegbe@yahoo.co.uk

Received November 25, 2017; Accepted November 30, 2017; Published December 10, 2017

Citation: Udegbe SE (2017) Nigerian Shoppers/Consumers Preferences for Foreign and Domestic Products: Case Study of Clothes and Shoes. J Account Mark 6: 258. doi: 10.4172/2168-9601.1000258

Copyright: (c) 2017 Udegbe SE. This is an open-access article distributed unde the terms of the Creative Commons Attribution License, which permits unrestricted use, distribution, and reproduction in any medium, provided the original author and source are credited. 


\section{Research Aims and Objectives}

The major aim of this study was to identify any significant differences or similarities for preference by shoppers/consumers for locally or foreign made clothes and shoes, so that recommendations could be made which will assist the foreign and local marketers operating in Nigeria. Key objectives:

1. The choice of Nigerian in using foreign products

2. The preference of Nigerians between a local and a foreign product

3. The perceptual choice of product choice of Nigerians with regards to its origin

4. The link of an imported product to a particular social group.

The following hypotheses were formulated and tested in order to achieve the objectives of the study:

H1: Nigerians will not show any difference between clothes/shoes made in Nigeria by a Nigerian firm and those made in a foreign country by a foreign firm.

$\mathrm{H} 2$ : All things being equal, considering clothes/shoes made in overseas by a foreign firm, Nigerians will not agree to pay a price premium to purchase clothes/shoes made by a foreign firm than that manufactured in Nigeria by a Nigerian firm.

H3: The willingness of Nigerians to pay a price premium for clothes/shoes manufactured in Nigeria by a Nigerian firm is a function of consumer's perception regarding the product's importance to Nigeria manufacturing base.

H4: Nigerians will prefer clothes/shoes manufactured overseas by a foreign firm if the product's price/quality mix is not even perceived to be significantly superior to that of a familiar product manufactured in Nigeria by a Nigerian firm.

\section{Literature Review}

In positioning a product, marketing managers combines marketing mix elements to optimize the product's profit contribution over time, and also involve in intense international trade expansion. The motivation for foreign production has been to enhance the firm's competitive advantage either by acquiring access to valuable markets. However, as posit by Ger [3], for consumers, when deciding between brands which are in the marketplace will include brands as an element to determine the qualities of the product rather than employing their time to enhance their knowledge of the product in information searching activities. Therefore, consumers use brands as cues to make decisions to purchase or try products.

Consumers value foreign brands compared to local brands especially for their assumed high quality and prestigious image [4]. If a product is perceived as globally available, consumers are likely to attribute a superior quality to the product, since such quality is thought of as a prerequisite for international acceptance [4-7]. An internationally well-established brand name can act as a "halo" constructs that effects quality beliefs [7]. According to Zeithaml [8] and Rowley [9] perceived quality is defined as the consumers' judgment about an entity's (service's) overall excellence or superiority.

Research also indicates that country of origin, price, social status, friends and family affects consumers perceptions toward products purchase decision $[1,4,10]$. Elliott and Cameron [11] define the country of origin effect as "the positive and negative influence that a product's country of manufacture may have on consumers' decision making processes or subsequent behaviour". In fact according to Nagashima [10], country of origin effect can be defined as "the picture, the reputation, and the stereotype that businessmen and consumers attach to products or brands of a specific country. This image is created by such variables as representative products, national characteristics, economic and political background, history, and traditions". Research also has it that country-oforigin effects is quite rich and covers the topic from different perspectives in different countries. Some studies have shown that country of origin also has symbolic and emotional meaning to consumers, and it plays an important role along with other attributes such as quality and reliability in shaping consumers attitudes toward products.

Likewise, according to Hansen [12], price is also one of the most important extrinsic cues that consumers use when evaluating the product/brand, and this determine at what point consumers are willing to forsake preference for local products for a greater price discount with foreign owned products. Researchers also stressed that consumers may prefer global brands because of associations of higher prestige $[4,13,14]$. Foreign products may have a higher prestige than local products due to their relative scarcity and higher price. Furthermore, foreign products may also stand for cosmopolitanism. Some consumers prefer foreign products because they enhance their self-image as being cosmopolitan, sophisticated, and modern. However, according to Ger [3], local brands tend to be targeted and positioned based on a deep cultural understanding and therefore create "a sustainable unique value and offer the symbolism of authenticity and prestige". Still, consumers have been found to have no intrinsic preference for global brands [15].

Many studies in the past have found out that, knowledge that consumers obtain through direct personal experience and reference groups will be perceived to be more trustworthy than information from other communications. Reference groups include groups or people whom one can look up for guidance and ask for opinion. These are important source of influencing the purchase decisions. Reference group include friends and family who influence ones buying decisions due to special skills, knowledge, and personality.

Extant literature have found out that, "domestic country bias" or "home country bias", consumer ethnocentrism, level of materialism, consumers' susceptibility to normative influence, country equity, value consciousness, consumers level of education, patriotic sentiments, different demographic characteristics of consumers, product type, and product familiarity influence consumers preference for products made in other countries [16-24].

Consumers may have a bias against foreign products and in favour of domestic ones $[16,17]$. According to extant literature, the explanation for domestic country bias is based on individual differences in terms of an individual personality trait called "ethnocentrism [25]. Consumer ethnocentrism describes the tendency of consumers to reject products from foreign countries and favor the domestic ones due to the beliefs held by consumers about the appropriateness and morality of purchasing foreign-made products $[16,18,25,26]$. Research suggests that materialism significantly affects consumer behavior in general, consumer perceptions, evaluations and preferences in particular. Materialistic consumers tend to display their status and possessions in their social groups [18]. They believe that purchasing imported luxury products demonstrates high levels of material achievement, and helps them make a good impression on others [20]. Therefore, gaining social status through their consumption of products is of importance for them.

Research also argues that highly materialistic consumers tend to 
evaluate brands from developing countries more unfavourably than consumers with low on materialism, because these brands may not help them gain social status [18]. Extant literature posits that consumers' susceptibility to normative influence, which is related to materialism, also affects consumers' evaluations and preferences [21,22].

Research suggests that country equity is a strong factor that explains the consumer perception influence [27]. This means that consumers tend to evaluate the brands originated from a country that has greater equity more positively than the brands originated from a country that has a lower or perhaps even negative equity $[17,22,28,29]$. It has also been indicated that highly value-conscious consumers in the emerging markets may evaluate products originated from developed countries more unfavourably, since the prices of these products are perceived to be higher than those of domestic ones [18]. Hence, "value consciousness" poses a threat to developed country brands in the global marketplace.

Likewise, past studies have indicated that consumers with high level of education tend to rate products from developed countries more favourably than do consumers with limited education [28]. Therefore, developed country brands may achieve less success in the markets with low education level than they do in the markets with high education level. Generally, extant literature has it that consumers attitude toward foreign origin vary significantly across product classes and image of manufacturer [1-28].

\section{Research Methodology}

This study is an empirical survey and was conducted to identify and analyze Nigerian shoppers/consumers preferences for foreign and domestic products as regard purchase of clothes and shoes. The sample for this research is made up of 600 shoppers/consumers of both youth and adults whose ages ranged from 16-60 years from Lagos. The respondents were selected based on convenience sample. The use of convenience sample has been found relevant in previous studies [30]. Questionnaires were used to collect primary data. The questionnaire included closed ended questions and Likert scale is used in most of the questions. These questionnaires were distributed to shoppers/ consumers in Lagos shopping malls and also Balogun/Tinubu market in Lagos Island-the most popular market for sales of clothes and shoes in Lagos.

Questionnaires with instructions were hand-delivered to respondents. Confidentiality was assured and incentive for participating in the research by making the report of the research available to the respondents if they so desire was promised. The variables measured were measured through a five point Likert scale ranging from very high extent (5) to no extent at all (1). 600 questionnaires were distributed and 542 completed questionnaires returned, out of which only 482 copies were found usable for the present study, resulting in an effective response rate of $80.33 \%$. Data were analyzed using descriptive statistics, percentages and t-test analysis. The research instrument showed high reliability and validity. The Cronbach alpha reliability coefficient measured 0.86 . This exceeds the value of 0.70 (suggesting adequate reliability, Cronbach [31]. The opinions of scholars of management and marketing confirmed the content validity of the measures used, while the pilot study result confirmed their predictive validity. The findings from the research were presented below.

\section{Findings and Discussion}

\section{Key to research variables used}

A1: Do Nigerians use foreign products?
A2: If a foreign product and a national product are priced same, would Nigerians prefer the foreign product?

A3: Do Nigerians consider where a product is manufactured when purchasing it?

A4: It is said that people buy foreign products so that they can be accepted in a particular social group. Do Nigerians agree?

A5: Nigerians will show difference between clothes/shoes made in Nigeria by a Nigerian firm and those made in a foreign country by a foreign firm

A6: All things being equal, considering clothes/shoes made in overseas by a foreign firm, Nigerians are more likely to pay a price premium to purchase clothes/shoes made by a foreign firm than that manufactured in Nigeria by a Nigerian firm.

A7: The willingness of Nigerians to pay a price premium for clothes/shoes manufactured in Nigeria by a Nigerian firm is not a function of consumer's perception regarding the product's importance to Nigeria manufacturing base. A8: Nigerians will prefer clothes /shoes manufactured overseas by a foreign firm if the product's price/quality mix is perceived to be significantly superior to that of a familiar product manufactured in Nigeria by a Nigerian firm.

From the mean values in Table 1 , it can be seen that all the variables (A1-A8) witnessed encouraging degree of practice and support the statement asked, and A1 (A1: do you use foreign products?) with mean value of 6.7261 having the highest extent of support to statement asked. Consumers value foreign brands compared to local brands especially for their assumed high quality and prestigious image [4]. Also, according to the data collected, $92.32 \%$ of the people used foreign products of which 201 were male and 244 were females. $6.5 \%$ of the people questioned claimed to use foreign products occasionally, whereas, $1.2 \%$ of the people claimed not to use at all. As indicated in the study above, more females used foreign products than male, and those who did not use the foreign product consisted of 5 males and 1 female out of the $1.2 \%$ that claimed not to use at all.

Likewise, A8 with mean value of 6.4205 (A8: Nigerians will prefer clothes/shoes manufactured overseas by a foreign firm if the product's price/quality $\mathrm{mix}$ is perceived to be significantly superior to that of a familiar product manufactured in Nigeria by a Nigerian firm) followed respectively. Based on surveyed respondents, variables A7 (A7: the willingness of Nigerians to pay a price premium for clothes/ shoes manufactured in Nigeria by a Nigerian firm is a function of consumer's perception regarding the product's importance to Nigeria manufacturing base) with mean value of 4.0620 received the least emphasis among the consumers surveyed. This can be explained by the willingness of Nigerian consumers to pay a higher price for Nigerian products is not a function of the product's perceived importance to the

\begin{tabular}{|c|c|c|c|c|}
\hline Variable & Mean & Standard Deviation & Skewness & Kurtosis \\
\hline A1 & 6.7261 & 1.5286 & -1.810 & 3.056 \\
\hline A2 & 5.6341 & 1.3173 & -1.702 & 2.842 \\
\hline A3 & 5.5217 & 1.2071 & -1.519 & 2.620 \\
\hline A4 & 5.4180 & 1.1903 & -1.317 & -2.521 \\
\hline A5 & 5.2375 & 1.1710 & -1.716 & 3.036 \\
\hline A6 & 5.3161 & 1.1854 & -1.412 & 2.866 \\
\hline A7 & 4.0620 & 1.0413 & -0.633 & 0.108 \\
\hline A8 & 6.4205 & 1.4273 & -1.794 & 2.966 \\
\hline
\end{tabular}

Table 1: Descriptive statistics of Nigerian shoppers/consumers preferences for foreign and domestic products measures $(n=482)$ [Source: Fieldwork 2017]. 
Nigerian products, but rather because of scarcity of foreign substitute, or government banned on foreign substitute.

From the research variable A2 (A2: If a foreign product and a national product are priced same, would you prefer the foreign product?), the purpose of this question was to evaluate and discover how important a factor such as price is in determining whether the consumers would go for the domestic product or stick to the foreign one if both the products were in the same price range. The results found out that $\mathrm{A} 2$ has a mean value of 5.6341, and it can be seen that the variable witnessed encouraging degree of support for the research question. Likewise, $86 \%$ of the consumers would go for the foreign products whereas $14 \%$ would still purchase the domestic ones. From personal observation, many Nigerians perceived Nigerian made goods as inferior in quality, and would rather buy superior quality relative to similar Nigerian products.

From the research variable A3 (A3: Do you consider where a product is manufactured when purchasing it?). This question was asked to discover how much importance customers lay on the country of origin as a factor when making a purchase. The results revealed that Nigerian customers purchase preferences as reported are more likely to be influence by the country in which the product is made than by the manufacturing company's national origin. The results found out that A3 has a mean value of 5.5217, and it can be seen that the variable witnessed encouraging degree of support for the research question. Likewise, majority of the consumers ( $78 \%$ males and $94 \%$ females) did consider where a product is manufactured as significant a factor as to affect his or her purchase decision. Nigerian consumers are only willing to pay more prices for foreign made goods if the goods are of significantly superior quality relative to similar Nigerian products.

From the research variable A4 (A4: It is said that people buy foreign products so that they can be accepted in a particular social group. Do you agree?). The results to these two questions confirmed the general perception that exists in our Nigerian society, that is, the foreign products are purchased as a status symbol. The customers mainly bought foreign made products to be able to fit in a particular social group. This occurs largely because social class pressure tends to be high at certain age, and most of the people find themselves being victims of inferiority complexes. The mean value to this question $\mathrm{A} 4=5.4180$ witnessed encouraging degree of support for the research question. The results to the first question indicated that on average $82 \%$ of the customers purchased the foreign and local products as a status symbol. These results were further enhanced by the results to the next question, which showed that $76 \%$ of the males and $84 \%$ of the females did, in fact, believe that the people purchased the foreign products to be able to fit in a particular social group.

\section{Test of research hypotheses}

Research hypothesis one (H1): Nigerians will not show any difference between clothes/shoes made in Nigeria by a Nigerian firm and those made in a foreign country by a foreign firm. From the mean column in Table 1, it can be seen that A5 "Nigerians will show difference between clothes/shoes made in Nigeria by a Nigerian firm and those made in a foreign country by a foreign firm" witnessed encouraging degree of mean value 5.2375, thus, experiencing encouraging support for the research question. Also, according to the data collected, $92.32 \%$ of the people used foreign products, while $6.5 \%$ of the people questioned claimed to use foreign products occasionally, whereas, $1.2 \%$ of the people claimed not to use at all.
Likewise, in the t-test analysis (not recorded here), when tested at 5 per cent level of significance, the $t$ score values for $A 5=3.174$. Since the $\mathrm{t}$-score values exceed the $\mathrm{t}$-table value of 1.96 , therefore the null hypothesis is rejected and the alternative hypothesis that "Nigerians will show difference between clothes/shoes made in Nigeria by a Nigerian firm and those made in a foreign country by a foreign firm" is hereby accepted. Extant literature has it that consumer purchase preferences are influence by the country in which the product is made than by the manufacturing company's national origin, and that consumers have significantly different perceptions about products made in different countries, and that these general perceptions have important effects on consumer's evaluation of the products manufactured in particular country $[23,24,32]$. Iyer and Kalita [32] also found that consumers display a preference for products made in some countries more than others. They have also found various other sources of biases that can influence consumers" preference for products made in different countries as ethnocentric bias, characteristics of consumers, patriotic sentiments, different demographic characteristics of consumers, product type, and product familiarity .

Research hypothesis two (H2): All things being equal, considering clothes/shoes made in overseas by a foreign firm, Nigerians will not agree to pay a price premium to purchase clothes/shoes made by a foreign firm than that manufactured in Nigeria by a Nigerian firm. From the mean column in Table 1, it can be seen that A6 "All things being equal, considering clothes/shoes made in overseas by a foreign firm, Nigerians are more likely to pay a price premium to purchase clothes/shoes made by a foreign firm than that manufactured in Nigeria by a Nigerian firm" witnessed encouraging degree of mean value 5.3161, thus, experiencing reasonable support for the research question.

Likewise, data collected indicated that $86 \%$ of the consumers would go for the foreign products whereas $14 \%$ would still purchase the domestic ones. Many Nigerians perceived Nigerian made goods as inferior in quality, and would rather buy superior quality relative to similar Nigerian products. Likewise, in the t-test analysis (not recorded here), when tested at 5 per cent level of significance, the t- score values for $\mathrm{A} 6=4.210$. Since the $\mathrm{t}$-score value exceed the $\mathrm{t}$-table value of 1.96 , therefore the null hypothesis is rejected and the alternative hypothesis that "all things being equal, considering clothes/shoes made in overseas by a foreign firm, Nigerians are more likely to pay a price premium to purchase clothes/shoes made by a foreign firm than that manufactured in Nigeria by a Nigerian firm" is hereby accepted. Research studies on consumer purchase preferences shows that the willingness of Nigerian consumers to pay a higher price for foreign products like clothes from USA and UK; shoes from Italy, USA and UK, because foreign products are significantly of superior quality relative to similar Nigerian products $[23,24,32]$. Researchers also stressed that consumers may prefer foreign products because of associations of higher prestige $[4,13,14]$. It is the believe that foreign products may have a higher prestige than local products due to their relative scarcity, higher price, and that foreign products may also stand for cosmopolitanism. Hence, some consumers prefer foreign products because they enhance their self-image as being cosmopolitan, sophisticated, and modern.

Research hypothesis three (H3): The willingness of Nigerians to pay a price premium for clothes/shoes manufactured in Nigeria by a Nigerian firm is a function of consumer's perception regarding the product's importance to Nigeria manufacturing base. From the mean column in Table 1, it can be seen that A7 "The willingness of Nigerians to pay a price premium for clothes/shoes manufactured in 
Nigeria by a Nigerian firm is not a function of consumer's perception regarding the product's importance to Nigeria manufacturing base" witnessed encouraging degree of mean value 4.0620 , thus, experiencing encouraging support for the research question, even though it is the variable with the least mean. Also, according to the respondent response, the willingness of Nigerian consumers to pay a higher price for Nigerian products is not a function of the product's perceived importance of the Nigerian manufacturing base, but rather, Nigerians positive attitudes towards the products made in their own country, and that the same respondents could be swayed to choose foreign products if quality and price consideration were sufficiently favourable. Likewise, in the t-test analysis (not recorded here), when tested at 5 per cent level of significance, the $t$ score values for $A 7=2.134$. Since the $t$-score values exceed the $t$-table value of 1.96 , therefore the null hypothesis is rejected and the alternative hypothesis that "the willingness of Nigerians to pay a price premium for clothes/shoes manufactured in Nigeria by a Nigerian firm is not a function of consumer's perception regarding the product's importance to Nigeria manufacturing base" is hereby accepted.

Research hypothesis four (H4): Nigerians will prefer clothes/ shoes manufactured overseas by a foreign firm if the product's price/ quality mix is not even perceived to be significantly superior to that of a familiar product manufactured in Nigeria by a Nigerian firm.

From the mean column in Table 1, it can be seen that A8 (A8: Nigerians will prefer clothes/shoes manufactured overseas by a foreign firm if the product's price/quality mix is perceived to be significantly superior to that of a familiar product manufactured in Nigeria by a Nigerian firm) witnessed encouraging degree of mean value 6.4205 , thus, experiencing encouraging support for the research question. Also, according to the respondents' response, respondents preferred product manufactured in foreign company if the product's price and quality mix was perceived to be superior. Evidence also revealed that the product's quality had to be twice as higher before the respondent was willing to trade up to the next price level. Likewise, in the t-test analysis (not recorded here), when tested at 5 per cent level of significance, the $\mathrm{t}$ score values for $\mathrm{A} 8=3.664$. Since the $\mathrm{t}$-score values exceed the t-table value of 1.96, therefore the null hypothesis is rejected and the alternative hypothesis that "Nigerians will prefer clothes/shoes manufactured overseas by a foreign firm if the product's price/quality mix is perceived to be significantly superior to that of a familiar product manufactured in Nigeria by a Nigerian firm" is hereby accepted. If a product is perceived as globally available, consumers are likely to attribute a superior quality to the product, since such quality is thought of as a prerequisite for international acceptance.

\section{Conclusion and Suggestion for Further Research}

This study has empirically investigated the Nigerian consumers' preferences for foreign and domestic products: case study of clothes and shoes. The study has been able to reveal that foreign products are purchased as a status symbol in Nigeria, and that customers mainly bought foreign made products to be able to fit into a particular social group. Hence, Nigerian consumers show more positive preference to foreign made clothes and shoes than to made in Nigeria, and they are willing to pay higher price for foreign made clothes and shoes because they are of more superior quality than made in Nigeria ones.

The study also indicated that Nigerian consumer purchase preferences are influence by the country in which the product is made than by the manufacturing company's national origin, and that consumers have significantly different perceptions about products made in different countries, and that these general perceptions have important effects on consumer's evaluation of the products manufactured in particular country. However the study have shown that in Nigeria consumer perception is being influenced by consumer ethnocentrism, level of materialism, consumers' susceptibility to normative influence, value consciousness, consumers level of education, demographic characteristics of consumers, product type, product price, product quality, and product familiarity.

The study confined itself to shoppers/traders in Lagos Nigeria. For effective generalization, this research therefore should be replicated in other states in Nigeria. Thus the findings may not be a thorough reflection of shoppers/consumers in Nigeria as a whole. These results may be useful to both academics and business practitioners with interest in the Nigerian economy.

\section{References}

1. Ogenyi O (2004) Nigerian consumers' preferences for foreign and domestic products: a study on footwear and wristwatches. AU Journal of Management 2.

2. Okechuku C, Onyemah V (1999) Nigerian consumer attitudes toward foreign and domestic products. Journal of International Business Studies 30: 611-622.

3. Ger G (1999) Localizing in the global village: Local firms competing in global markets. California Management Review 41: 64-83.

4. Steenkamp JB, Batra R, Alden DL (2003) How perceived brand globalness creates brand value. Journal of International Business Studies 34: 53-65.

5. Ismail Z, Masood S, Tawab ZM (2012) Factors affecting consumer preference of international brands over local brands. In $2^{\text {nd }}$ International Conference on Social Science and Humanity IPEDR 2012.

6. Zemenu A (2014) Factors affecting customers attitude among foreign and domestic footwear product. International Journal of Academic Scientific Research 2: 13-20.

7. Han CM (1989) Country image: halo or summary construct? Journal of Marketing Research 26: 222

8. Zeithaml VA (1988) Consumer perceptions of price, quality, and value: a means-end model and synthesis of evidence. The Journal of Marketing, p: 2.

9. Rowley J (1998) Quality measurement in the public sector: Some perspectives from the service quality literature. Total Quality Management 9: 321-333.

10. Nagashima A (1970) A comparison of Japanese and US attitudes toward foreign products. The Journal of Marketing, pp: 68-74.

11. Elliott GR, Cameron RC (1994) Consumer perception of product quality and the country-of-origin effect. Journal of International Marketing, pp: 49-62.

12. Hansen T (2005) Perspectives on consumer decision making: An integrated approach. Journal of Consumer Behaviour 4: 420-437.

13. Schuiling I, Kapferer JN (2004) Executive insights: real differences between local and international brands: strategic implications for international marketers. Journal of International Marketing 12: 97-112.

14. Shocker AD, Srivastava RK, Ruekert RW (1994) Challenges and opportunities facing brand management: An introduction to the special issue. Journal of Marketing Research 31: 149-158.

15. De Mooij M (2010) Consumer behavior and culture: Consequences for global marketing and advertising. Sage.

16. Balabanis G, Diamantopoulos A, Mueller RD, Melewar TC (2001) The impac of nationalism, patriotism and internationalism on consumer ethnocentric tendencies. Journal of International Business Studies, pp: 157-175.

17. Verlegh PW, Steenkamp JB (1999) A review and meta-analysis of country-oforigin research. Journal of Economic Psychology 20: 521-546.

18. Sharma P (2011) Demystifying cultural differences in country-of-origin effects: exploring the moderating roles of product type, consumption context, and involvement. Journal of International Consumer Marketing 23: 344-364.

19. Jiménez NH, San Martín S (2010) The role of country-of-origin, ethnocentrism and animosity in promoting consumer trust. The moderating role of familiarity International Business Review 19: 34-45. 
Citation: Udegbe SE (2017) Nigerian Shoppers/Consumers Preferences for Foreign and Domestic Products: Case Study of Clothes and Shoes. J Account Mark 6: 258. doi: 10.4172/2168-9601.1000258

Page 6 of 6

20. Kilbourne W, Günhagen M, Foley J (2005) A cross-cultural examination of the relationship between materialism and individual values. Journal of Economic Psychology 26: 624-641.

21. Chapa S, Hausman A (2010) Exploring the Country-of-Origin Indicators across Product Categories: The Case of Mexico and Chile. Multidisciplinary Business Review 3: 33-49.

22. Batra R, Ramaswamy V, Alden DL, Steenkamp JB, Ramachander S (2000) Effects of brand local and nonlocal origin on consumer attitudes in developing countries. Journal of Consumer Psychology 9: 83-95.

23. Ahmed ZU, Johnson JP, Pei Ling C, Wai Fang T, Kah Hui A (2002) Country-oforigin and brand effects on consumers' evaluations of cruise lines. International Marketing Review 19: 279-302.

24. Ede FO, Panigrahi B (2000) African-American consumer attitudes toward domestic and foreign-made automobiles. Management Research News 23: 1-9.

25. Peterson RA, Jolibert AJ (1995) A meta-analysis of country-of-origin effects. Journal of International Business Studies 26: 883-900.

26. Lantz G, Loeb S (1996) Country of origin and ethnocentrism: an analysis of
Canadian and American preferences using social identity theory. ACR North American Advances.

27. Zeugner-Roth KP, Žabkar V, Diamantopoulos A (2015) Consumer ethnocentrism, national identity, and consumer cosmopolitanism as drivers of consumer behavior: A social identity theory perspective. Journal of International Marketing 23: 25-54.

28. Bilkey WJ, Nes E (1982) Country-of-origin effects on product evaluations. Journal of International Business Studies 13: 89-100.

29. Cordell VV (1992) Effects of consumer preferences for foreign sourced products. Journal of International Business Studies 23: 251-269.

30. Hall J, Lockshin L (2000) Using means-end chains for analysing occasions-not buyers. Australasian Marketing Journal 8: 45-54.

31. Cronbach L (1947) Test "reliability": Its meaning and determination. Psychometrica 16: 1-16.

32. Iyer GR, Kalita JK (1997) The impact of country-of-origin and country-ofmanufacture cues on consumer perceptions of quality and value. Journal of Global Marketing 11: 7-28. 